\title{
Using Military Vocabulary and Concepts for Successful Language Learning at the Defence University
}

\author{
Jowati binti Juhary \\ Language Centre, National Defence University of Malaysia (UPNM)
}

\begin{abstract}
This study attempts to review the English language courses at the National Defence University of Malaysia (NDUM). Although English language is accepted as a universal language, the roles played by the future military officers require the university to prepare its graduates with the ability to not only master the language, that is, to become communicatively competent, but also to function effectively during peacekeeping and humanitarian operations. It is argued that when the language courses do not match the stakeholders and students' expectations and needs, the students particularly appear to be less inclined to learn the target language. This research focuses on whether students have been undergoing appropriate English language courses for their future needs as officers of the armed forces. The methodology of this paper involves distributing and collecting data from 167 students of the university. Data were then analysed using Statistical Packages for Social Sciences (SPSS) Version 16. Findings suggest that students are positive about learning English language. Nonetheless, they have raised several issues that must be addressed immediately by the English instructors. As this research is still collecting data from other sets of respondents, suffice to conclude at this point that military vocabulary and concepts will better assist students in English language learning.
\end{abstract}

\section{Introduction}

This work attempts to review the English language courses at the National Defence University of Malaysia (NDUM). English language courses are compulsory university courses in most higher learning institutions in Malaysia. Undergraduate students may need to undertake about six to eight English language course credits for their entire duration as tertiary education students. Coupled with this, the students have undergone English language courses during their 11 years of primary and secondary learning. It is still a puzzle though why graduates appear to have difficulties in securing jobs.

It is reported that one of the reasons is students' lack of English language proficiency. Obviously, this has created tension at the ministerial level, and one of the possible solutions to this issue is to strengthen students' communication skills through the implementation of Generic Students Attributes (GSA) at higher learning institutions. Nonetheless, future graduates of the NDUM must be trained not only to face the uncertainties of the $21^{\text {st }}$ century, but they must also be taught to deal with the routines of peacekeeping and humanitarian operations. These skills require them to have "communicative competence" using English language as a medium. Their failure to articulate their thoughts in English reflects the failure of the NDUM and the country to educate and inspire the young officers.

Before discussing further, the organisation of this paper will be outlined. There are six sections including this introduction. The second section discusses the significance of the research by presenting the research objectives, hypothesis and questions. The third section examines selected literature on English language learning particularly English for Specific Purposes (ESP). The fourth section explains the research methodology of this research. Next, the most critical section analyses the findings of this paper by providing answers to the research questions. The last section closes the paper with conclusions and suggestions.

\section{Significance of the Study}

The question addressed in this paper is whether the defence university has been preparing the graduates to become communicatively competent in the context of defence and security. The research focuses on whether students have been undergoing appropriate English language courses for their future needs as officers of the armed forces. It is argued that when the language courses do not match the stakeholders and students' expectations and needs, the students appear to be less inclined to learn the target language [1][2][3][4][5][6], and in the defence university's case, the target language is English. At the same time, the inability of students to utilise their language skills has made this research a timely endeavour by the researcher. The researcher, who is also an academic at the NDUM, has been with the defence university since its inception in 2006. After running for seven years and producing its own graduates of 148 in 2010, 407 in 2011 and 390 in 2012, the English language courses undoubtedly need to be reviewed and necessary changes employed. 


\subsection{Research Objectives}

- To identify students' English language requirements who will serve the Malaysian Armed Forces (MAF), the biggest stakeholder of the NDUM.

- To evaluate the existing English language courses at the NDUM.

- To identify significant themes that will contribute to military vocabulary and concepts of the students.

- To determine what improvements should be in place to educate future officers in the professions of arms.

\subsection{Research Hypothesis}

The hypothesis of this research is that "English language courses at the NDUM do not prepare students to face their future vocation effectively because the courses lack integration of military vocabulary and concepts." It is thus critical the curricula and syllabi of the language courses are reviewed and military components must be integrated systematically. This includes important vocabulary and concepts used in military institutions.

\subsection{Research Questions}

This paper is part of a bigger research project (see Methodology section). At the time of writing this paper, data were collected from 167 students only. It needs to be emphasised that because the data have not been fully collected yet, some of the research questions may not be fully answered based on the current available data.

To respond to the objectives of this research, the questions addressed are,

- How important are the English language skills to the future military officers?

- What are the English language requirements and needs of the students?

- What are the critical military concepts that must be integrated in the curricula and syllabi?

- How best to teach English language courses at the NDUM?

\section{Selected Literature}

Curricula and materials used in instruction (commercial textbooks and teacher-produced materials) should match the goals of the students. It is a challenge to address students' interests when a variety of goals for developing literacy are represented in one class or course. At the NDUM, the English language courses are compulsory university courses that must be taken and passed by all students.
The main question that must be addressed is how to ensure that students do not only undertake the courses to complete their degree requirements; but more importantly is whether they are able to use the language effectively and efficiently during and after their studies. In order to ensure that students benefit from English language classes, their needs for learning the target language must match their own motivation. Another concern that will be addressed in this research is on the students' lack of military concepts and vocabulary in English language. This has hindered them from communicating effectively, and has made the students appear to be passive participants in language classrooms [7].

Given the concerns of this research, it is argued that the best approach to ensure successful language learning is to revamp the curricula and syllabi of English language courses at the NDUM. There has been no attempt to revisit the curricula and syllabi of all English language courses since the university's inception in 2006. It is argued that the implementation of ESP could help both language instructors and students to undergo the process of language teaching and learning better.

On the whole, studies about ESP are abundant. The most recent ones argue for the advantages of using Problem Based Learning (PBL) in ESP classrooms [8] and the implications of ESP that could lead to various ways to improve English language courses for tertiary education [9]. Notwithstanding this, none of the research has ever focused on ESP for the military and defence needs. At the NDUM, all students undergo generic English language courses that use different materials for students of differing majors.

On a larger scale, there have been a lot of debates on what ESP is for. In Malaysia, there are studies on ESP which focus on the language needs of the students [10][11][12]. These studies argue on how the needs analysis could help educators identify the students' requirements for learning the target language. The key finding of these studies emphasises on the risks of ignoring the needs analysis when designing the ESP courses. This aspect clearly becomes vital for the NDUM in its attempt to revisit the curricula and syllabi of the English courses.

Of late, ESP has been viewed as not necessarily related to a specific discipline and it is most successfully used with adult learners [13]. Further, in discussing and analysing ESP, one may use three types of ESP as identified by Carter [14],

- English as a restricted language

- English for Academic and Occupational Purposes

- English with specific topics

In the NDUM setting, the researcher opts for the second type of ESP as recognised by Carter. In the 
'Tree of English Language Teaching' [15], ESP is broken down into three branches: a) English for Science and Technology (EST), b) English for Business and Economics (EBE), and c) English for Social Studies (ESS). Each of these subject areas is further divided into two branches: English for Academic Purposes (EAP) and English for Occupational Purposes (EOP). An example of EOP for the EST branch is 'English for Technicians' and an example of EAP for the EST branch is 'English for Medical Studies.'

Essentially, there is no clear demarcation between EAP and EOP. As military cadets at the NDUM study and 'work' at the same time, their needs for ESP is inevitable. The military cadets receive monthly salary from the Ministry of Defence Malaysia (MINDEF) because they are considered active personnel. Therefore, for military cadets, the end result of learning English would be the same employment purposes. It is noted that there is no categorisation for military branch. However, the researcher would like to assume that military skills and learning texts come under EST because most materials involve discussion related to science and technology.

In addition, Butler-Pascoe [16] suggested that practitioners of ESP have three primary models that can be used in designing their language curriculum.

- ESP taught by English teachers using field specific content

- Field specific courses taught by the teachers using English as the medium of instruction

- A collaborative model in which both English and field specific teachers have joint input into the development and/or teaching of the course

For the NDUM, the first model has been adopted since its inception for English language teaching. The second model is almost non-existence since most educators will use mixed languages, that are Bahasa Melayu and English, in their teaching sessions and the third model has never been strategised before.

In addition, the adoption of ESP is rather prominent in business studies, laws and medicine. Given the lack of research on military English in this region, it is the responsibility of those teaching at the first defence university in Malaysia to provide some innovative and creative ways of dealing with the loophole. Hull [17] proposed that the method of curriculum design and delivery for Medical English needs "to shift from the traditional audio-lingual method to being contextually based and experiential." She further stressed on the needs to teach English for career preparation rather than for structural foundations and rules of learning a new language. Therefore, should the military cadets at the NDUM be taught English courses for their career or degree requirements? The researcher opines that it is for both and this will be substantiated in the fifth section later.

\section{Methodology}

This descriptive research employs a mixed method approach. Qualitative data will be gathered using semi-structured interviews with military personnel of the Education Directorate as well as officers at the Human Resource Branch at the MINDEF and language instructors at the NDUM. The researcher will need to get permission and clearance prior to meeting and conducting interviews with potential respondents. A letter of exploratory statement will be issued to each respondent to explain the purposes of this research. Further, quantitative data will be collected using questionnaires distributed to only military students of the university (the NDUM has about 70 percent military cadets and 30 percent civilians and/or Reserved Officers under the Reserved Officers Training Unit (ROTU) scheme). Data collection involves several stages. At this stage, the researcher just started collecting quantitative data through surveys and four language instructors have also been interviewed (qualitative data).

\subsection{Research Respondents}

The respondents of this research are divided into three: the language instructors at the NDUM, the military personnel at the MINDEF, and all military cadets of the NDUM. It must be emphasised that respondents at the MINDEF will be nominated by their heads of departments. Further, the military personnel at the MINDEF will be officers at the Education Directorate and the Human Resources Department. Table 1 summarises the respondents' profiles.

Table 1: The Number of Interview and Survey Respondents

\begin{tabular}{|l|c|}
\hline Organisations & Number of Respondents \\
\hline \multicolumn{2}{|c|}{ Interview Respondents } \\
\hline $\begin{array}{l}\text { National Defence } \\
\text { University of } \\
\text { Malaysia }\end{array}$ & $\begin{array}{c}16 \\
\text { (all English Language } \\
\text { Instructors) } \\
\text { (as at 15 March 2013) }\end{array}$ \\
\hline $\begin{array}{l}\text { Ministry of Defence } \\
\text { Malaysia }\end{array}$ & 9 \\
\hline
\end{tabular}




\begin{tabular}{|c|c|}
\hline $\begin{array}{l}\text { - The Education } \\
\text { Directorate }\end{array}$ & $\begin{array}{c}\text { military service } \\
\text { including Malaysian } \\
\text { Army, Royal } \\
\text { Malaysian Navy and } \\
\text { Royal Malaysian Air } \\
\text { Force) }\end{array}$ \\
\hline $\begin{array}{l}\text { - The Human } \\
\text { Resources } \\
\text { Department }\end{array}$ & 5 \\
\hline \multicolumn{2}{|c|}{$\begin{array}{l}\text { Survey Respondents } \\
\end{array}$} \\
\hline $\begin{array}{l}\text { National Defence } \\
\text { University of } \\
\text { Malaysia }\end{array}$ & $\begin{array}{c}1,181 \text { (all military } \\
\text { cadets) } \\
\text { (as at } 15 \text { March 2013) }\end{array}$ \\
\hline $\begin{array}{l}\text { Total Number of } \\
\text { Respondents }\end{array}$ & $\begin{array}{l}\text { Interview }-30 \\
\text { respondents Survey - } \\
1,181 \text { respondents }\end{array}$ \\
\hline
\end{tabular}

As was mentioned previously, the data had been collected from 14 percent of the total population of military cadets, 167 . The process of data collection is still ongoing and interviews with the English instructors have just begun.

\subsection{Research Instruments}

The instrument of this research is a series of items based on the hypothesis and research questions described earlier. Semi-structured interviews allow the researcher to modify the questions asked depending on the positions, experiences and expertise of the interviewees. In general, there are about seven main questions that will be asked including the military concepts that must be included in the language courses and the depth of each military concept.

Further, a set of adopted questionnaires by $\mathrm{Al}-$ Tamimi and Shuib [18] will be distributed to military students of the NDUM, amounting to 1,181 in number. There are seven main sections in the questionnaires, including demographic section, students' ability to perform tasks based on themes and the significance of the language skills to the students. Before the questionnaires are distributed, a pilot test was performed in order to check for reliability and validity of the instrument. The most important agendas, amongst others, are to check whether languages used in the questionnaires will hinder respondents' comprehension of the items asked, and to gauge whether students are able to understand what they are supposed to comprehend; in this way, the intended questions by the researcher must match students' own framework of understanding.

As was explained earlier, the respondents at the MINDEF will be nominated by their heads of departments. Before the interview starts, the respondents will be briefed on their rights and they will need to sign a consent form that states information on their rights. All interviews will be tape recorded for future reference. The respondents may also withdraw from the interview if they want to do so. As a token of appreciation, they will be given a souvenir. Each interview may take up to a maximum of 45 minutes.

On the other hand, since all cadets will have to participate in the survey, the researcher will engage their time during the last 15 minutes of a tutorial or lecture session. The survey may take between 10 to 15 minutes. The 167 returned questionnaires required students to complete in an average of eight minutes. The researcher is actively involved in the process by distributing, explaining concepts as well as collecting the questionnaires from the students. In this way, the students will be more cooperative while completing the questionnaires. It is important too, to brief the students that they must attempt to answer honestly the questions because the findings of this survey will improve their learning experience of English language.

\subsection{Data Analysis}

After each interview session, the researcher will transcribe the dialogues. These will then be processed using NViVo in order to examine critically the issues discussed. Prior to that, the themes of the analysis and discussion will be determined according to the existing literature on English language learning. The researcher has finished interviews with four language instructors; however transcription has not been completed. What can be reported on the recurring themes of the interviews will appear in the next section.

Further, the data gathered from the survey are analysed using the Statistical Packages for Social Sciences (SPSS) Version 16. All collected/returned questionnaires are labelled prior to processing the information using the software. Due to the incomplete data set, this paper will only use descriptive statistics to substantiate the arguments made.

All in all, the study uses a methodology that combines both quantitative (through surveys) and qualitative (through individual interviews) data for analysis. In this case, qualitative data are essential for understanding the rationale underlying the relationships revealed by the quantitative data; qualitative information can also reveal other factors that influence institutional outcomes, and these can then be analysed more deeply by quantitative methods [19]. These quantitative and qualitative research approaches are best viewed as complementary rather than competitive; this perspective enables a researcher to combine the best features of both approaches. Thus, the hypothesis and research questions will be tested through the 
triangulation of both quantitative and qualitative data.

\section{Findings and Analysis}

This research and its findings are highly critical because they challenge the youngest public university in Malaysia, the NDUM, to strengthen its teaching and learning environment and experiences. One way of doing this is by re-evaluating the existing educational system and curricula. It is a tough task, and yet must be braved in order to fulfil the demands of the students. This section will present the findings of the 167 returned questionnaires and then examine the issues together with the data from the interviews with the language instructors. Although the findings of the qualitative data are inconclusive, they may provide an important pattern and trend of language teaching and learning at the NDUM.

Table 2 summarises the demographic data of the 167 students who have answered the questionnaires.

Table 2: The Demographic Information of the Respondents

\begin{tabular}{|l|l|l|}
\hline Items & Responses (in percentages) \\
\hline Gender & Male & 89 \\
& Female & 11 \\
\hline Military Services & Army & 38 \\
& Navy & 35 \\
& Air Force & 27 \\
\hline The MUET Result & Band 4 & 1 \\
& Band 3 & 21 \\
& Band 2 & 62 \\
Have Taken & Band 1 & 16 \\
English for & 81 & \\
Academic Writing & & \\
\hline Have Taken & 44 \\
English for Oral & \multicolumn{2}{|}{} \\
Communication & \\
\hline
\end{tabular}

To further understand the discussion, three of the items in Table 2 need to be explained. The MUET refers to the Malaysian University English Test, which is one of the requirements to enter Malaysian public universities. The score of the test is divided into six bands; Band 6 is the highest and Band 1 is the lowest. The next two items are the compulsory university courses for English language. English for Academic Writing focuses on writing competency and is the first language course that must be taken. English for Oral Communication is the last English language course and as the name suggests, it focuses on oral communication skills of the students.

The NDUM is not an exclusive male institution; nonetheless, the number of female students is rather small. This reflects the requirements of the MAF for female officers. Due to a small number of units or branches that can have female officers, the MAF has no option but to limit the number of its female intake. This can be illustrated in the number of female respondents in Table 2, which actually reflects the number of female student populations at the defence university. In terms of military services, the NDUM houses more Army cadets than the Navy and Air Force. Once again, this portrays the strengths of the personnel in each service in the MAF and the number of bases associated with the services [20].

The results of the MUET suggest that the students are quite poor at English language at the point of joining the defence university. It further increases the needs to provide the students with military concepts and vocabulary in order to assist them to reach their potential in language learning. But this is just the assumption of the researcher. Data to prove this assumption will be presented later in this section.

This paper is not to present the whole data collected from the 167 returned questionnaires; rather only selected key items will be analysed. Given the full set of data from other respondents have not been gathered yet, it is impractical to present the analysis of some items at this stage. In general, there are five items to be analysed and discussed in this paper. The following paragraphs will examine the items in detail.

The first item is illustrated in Table 3 below. It appears that the majority of the respondents agreed that the time allocated for English language courses is sufficient. At the NDUM, each English course has a 42-hour face-to-face session with the instructors (one semester has 14 academic weeks). Only 35 percent of the respondents (about 58 students) felt that the 3-hour per week session is not enough. Initial conclusion suggests that students may perceive that 3 hours per week are adequate given that all other core courses have similar contact hours. Contrary to this, the language instructors felt differently about the contact hours. According to Interview Respondent (IR) A, the hours should be longer, at least by one or two hours in order to better support the students. Given their poor achievement in the MUET exam, students need ample time to practise and use the target language.

Table 3: Item 1

\begin{tabular}{|l|l|l|}
\hline Questionnaire Item & \multicolumn{2}{|l|}{$\begin{array}{l}\text { Responses } \\
\text { percentages) }\end{array}$} \\
\hline $\begin{array}{l}\text { Is the time allocated to the } \\
\text { English course enough to } \\
\text { use the language } \\
\text { effectively? }\end{array}$ & No & 65 \\
\hline
\end{tabular}

The second item requires the respondents to choose from a five-likert scale answer on the 
usefulness of English language courses for them. The results of this item is summarised in Table 4. What can be discerned from Table 4 is that about 30 percent of the respondents failed to see the usefulness of the language courses. To explain this scenario, the researcher would like to summarise the points from IR D who put forth the fact that due to the generic English language courses offered to students, these military cadets may fail to relate their needs to the generic skills. What they require is more exposure on military terms and concepts. This claim is further supported by the responses of the next item to be discussed which is illustrated in Table 5 .

Table 4: Item 2

\begin{tabular}{|l|l|l|}
\hline $\begin{array}{l}\text { Questionnaire } \\
\text { Item }\end{array}$ & \multicolumn{2}{|l|}{ Responses (in percentages) } \\
\hline How useful is the & Very useful & 24 \\
English language & Useful & 47 \\
course with & Of some use & 15 \\
regards to your & Of little use & 8 \\
language needs? & Not useful & 6 \\
\hline
\end{tabular}

Table 5: Item 3

\begin{tabular}{|l|l|l|}
\hline Questionnaire Item & Responses (in percentages) \\
\hline Do you think you & Strongly Agree & 85 \\
should be exposed & Agree & 14 \\
to military & Not sure & 1 \\
concepts and & Disagree & 0 \\
vocabulary in & Strongly Disagree & 0 \\
English language & & \\
courses? & & \\
\hline
\end{tabular}

Table 5 clearly presents the perceptions of the respondents on the importance of military concepts and vocabulary. It needs to be explained that students do have military classes and the medium of instruction for these classes is Bahasa Melayu. It is argued that for the future military officers to function in this unknown world, they must be fully equipped: physically, spiritually, mentally and academically. Hence, this is where their ability to communicate effectively in English will reflect their level of confidence and performance.

The fourth item is presented in Tables $6 \mathrm{a}$ and $6 \mathrm{~b}$. Based on Table $6 a$, it can be concluded that respondents felt the needs to read military articles and journals, online materials and study notes the most as are exemplified by the mean score of these skills (3.209, 3.148 and 3.123 respectively). What this finding suggests brings two main implications. First, as can be seen in Table 5, the respondents are in serious need of military terminology and concepts. As their future vocation depends on their proficiency of military terms and values, their responses in Tables $6 \mathrm{a}$ and $6 \mathrm{~b}$ seem appropriate.
Second, these students are undoubtedly digital natives and Net Generation [21][22]. Borne after the 1980 s, their way of perceiving and responding to learning materials and environment is different from tertiary students three decades ago. These digital natives rely heavily on the Internet technologies for almost everything. This is supported by the students' responses on reading printed materials; the means of reading textbooks and technical manuals recorded 2.963 and 2.950 respectively.

The same pattern can be seen in Table 6b. The responses on the needs of learning English are complemented with what they perceived as important language skills to them. The highest mean still goes to reading military articles/journals, followed by reading texts on computers. It needs to be highlighted that a few respondents asked the meaning of reading texts on computer; is it referring to online materials available or using the existing Learning Management System (LMS)? The researcher did not realise this sub item will pose difficulties to the students because it did not during the pilot test. The researcher then explained that whatever forms of online learning strategies are acceptable. This issue is then resolved by adding the relevant information in the questionnaires distributed after that.

\section{Table 6a: Item 4a}

\begin{tabular}{|c|c|c|c|}
\hline $\begin{array}{l}\text { Questionnaire } \\
\text { Item }\end{array}$ & Reading Skills & Mean & $\begin{array}{c}\mathrm{O} / \mathrm{L} \\
\text { Mean }\end{array}$ \\
\hline $\begin{array}{l}\text { Students' } \\
\text { needs of } \\
\text { English } \\
\text { language } \\
\text { training }\end{array}$ & $\begin{array}{l}\text { Reading Textbooks } \\
\text { Reading Military } \\
\text { Articles/Journals } \\
\text { Reading Technical } \\
\text { Manuals } \\
\text { Reading texts on } \\
\text { computer } \\
\text { Reading study notes }\end{array}$ & $\begin{array}{l}2.963 \\
3.209 \\
2.950 \\
3.148 \\
3.123\end{array}$ & 3.078 \\
\hline
\end{tabular}

Note: O/L is Overall

Table 6b: Item 4b

\begin{tabular}{|l|l|c|c|}
\hline $\begin{array}{l}\text { Questionnaire } \\
\text { Item }\end{array}$ & Reading Skills & Mean & $\begin{array}{c}\text { O/L } \\
\text { Mean }\end{array}$ \\
\hline $\begin{array}{l}\text { Importance of } \\
\text { the skills to } \\
\text { students }\end{array}$ & $\begin{array}{l}\text { Reading Textbooks } \\
\text { Reading Military } \\
\text { Articles/Journals } \\
\text { Reading Technical } \\
\text { Manuals } \\
\text { Reading texts on } \\
\text { computer } \\
\text { Reading study notes }\end{array}$ & 4.250 & 3.295 \\
4.271 & 3.857 \\
\hline
\end{tabular}

Note: O/L is Overall

The finding of the last item to be discussed is illustrated in Table 7. The high percentages of responses for military related exposure further 
strengthen the arguments that these military cadets require different learning materials and experience. This further suggests that the curricula and syllabi of the language courses must be revisited. IR C opined that the students need to be given learning materials that relate to their future careers so that they feel more motivated and ultimately, find the language useful. From the list of choices, the lowest percentage is general term; perhaps this denotes the students' perceptions of their language requirements for learning English general vocabulary.

Table 7: Item 5

\begin{tabular}{|c|c|c|}
\hline $\begin{array}{l}\text { Questionnaire } \\
\text { Item }\end{array}$ & Choices & $\begin{array}{l}\text { Responses (in } \\
\text { percentages) }\end{array}$ \\
\hline Which aspects & Grammar & 68 \\
\hline of the English & Technical Terms & 55 \\
\hline language & General Terms & 51 \\
\hline course that & Military Terms & 78 \\
\hline you should & Military Concepts & 86 \\
\hline have more & Communication & 84 \\
\hline training? (can & Reading & 67 \\
\hline choose more & Writing & 75 \\
\hline $\begin{array}{l}\text { than one } \\
\text { answer) }\end{array}$ & Listening & 68 \\
\hline
\end{tabular}

Testing the research hypothesis at this stage may not be quite relevant. Nonetheless, looking at the data gathered so far, it is reasonable to conclude that the hypothesis can be accepted, that "English language courses at the NDUM do not prepare students to face their future vocation effectively because the courses lack integration of military vocabulary and concepts." As to the research questions, some preliminary answers can be formulated as listed below, but only for the first two.

- How important are the English language skills to the future military officers?

It appears that English language skills are very important for these future officers of the MAF. The active involvement of the MAF in peacekeeping and humanitarian operations requires the officers to be communicatively competent. Their ability to use English will only come with some level of confidence. In actual fact the students' confidence originates from knowing that they have the 'right' terms and concepts to use when communicating on the field.

- What are the English language requirements and needs of the students?

Based on the responses, students require exposure to military bias texts, terms and concepts during their English language lessons. All these must be blended with other aspects of language learning as can be illustrated in Table 7 . Notwithstanding this, the language instructors must be imaginative in creating a learning environment that invites students to participate actively during learning processes. The use of various types of materials and the Internet resources as well as e-learning platform may give students the learning choices that suit them best.

\section{Conclusion}

It is expected that this research will be able to identify the weaknesses of the current English language curricula and syllabi and thus, using the input from students, teachers and stakeholders, the curricula and syllabi will be improved. This improvement will reflect the crucial transformation aspired by the MAF in playing its roles in the region. The findings of this research will be able to ensure a more dynamic approach to teaching and learning of English language for military cadets.

Looking at the findings of this paper, one may wonder whether the NDUM has done its best especially in terms of English language learning and teaching. To the instructors' defend, including the researcher, the curricula and syllabi of the two English language courses do have some ESP components in them; military as well as academic major based materials. The researcher has yet to determine as to the reasons why instructors do not use the materials available in the main course folders. Or perhaps they have used the materials but the execution strategies may be incorrect. Personally, the researcher is currently engaged with future navigators of the Royal Malaysian Navy ships, and thus materials used for reading and speaking have a mixture of maritime related components as well as general military English. Reports on any improvement of the students' proficiency and confidence have to wait since the semester has just started.

To conclude, this research may assist the development of robust curricula for the teaching and learning of English at the defence university. After seven years of inception, it is high time to revisit what and how students are taught during their English lessons. Military vocabulary and concepts may facilitate faster understanding and learning of English language, and gradually improve cadets' English proficiency and competency.

\section{References}

[1] R.C. Gardner. Social Psychology and Second Language Learning: The Role of Attitude and Motivation. Edward Arnold, 1985.

[2] A.M. Masgoret and R.C. Gardner. Attitudes, Motivation and Second Language Learning: A Meta Analysis of Studies Conducted by Gardner and Associates. Language Learning. 2003, 53 (Suppl. 1): 167-210.

[3] F. Morris. Language Learning Motivation for the Class 
of 2002: Why First Year Puerto Rican High School Students Learn English. Language and Education. 2001, 15: $269-278$.

[4] R. Oxford and J. Shearin. Language Learning Motivation: Expanding the Theoretical Framework. Modern Language Journal. 1994, 78: 12-28.

[5] Z. Dornyei and K. Csizer. Ten Commandments for Motivating Language Learners: Results of an Empirical Study. Language Teaching Research. 1998, 4: 203-229.

[6] K, Weddel and C. van Duzer. Needs Assessment for Adult ESL Learners. National Centre for ESL Literacy Education, 1997.

[7] J. Jowati. A Military Learning Environment: The Malaysian Experience. Lambert Academic Publishing, 2010.

[8] E.M. Anthony. Problem-Based Learning (PBL): A Source of Learning Opportunities in Undergraduate English for Specific Purposes. Paper presented at IATEFL. 2010 .

[9] A.S. Al-Thamimi and M. Shuib. Investigating the English Language Needs of Petroleum Engineering Students at Hadhramout University of Science and Technology. The Asian ESP Journal. 2010, 6 (1): 6-34.

[10] H. Chin. An Analysis of the Needs of Form 5 Learners in the Teaching and Learning of EST (English for Science and Technology) in Two Rural Schools. Unpublished Master Dissertation. Universiti Sains Malaysia, 2004.

[11] S. Rahim. A Needs Analysis of Communication Skills Required by Engineering Undergraduates in UiTM Penang. Unpublished Master Dissertation. Universiti Sains Malaysia, 2005.

[12] H. Stapa and M. Jais. A Survey of Writing Needs and Expectations of Hotel Management and Tourism Students. ESP World. 2005, 1 (4). Retrieved 2 February 2013 from $\mathrm{htt} / / / \mathrm{www}$. esp-world.info/Articles_9/issue_9.htm.

[13] T. Dudley-Evans and M. St John. Developments in ESP: A Multidisciplinary Approach. Cambridge University Press, 1998.

[14] D. Carter. Some Propositions about ESP. The ESP Journal. 1983, 2: 131-197.

[15] T. Hutchinson and Waters, A. English for Specific Purposes: A Learning-Centred Approach. Cambridge University Press, 1987.

[16] M. E. Butler-Pascoe. English for Specific Purposes (ESP), Innovation and Technology. English Education and ESP. 2009, June: 1-15.

[17] M. Hull. Changing the Paradigm for Medical English Language Teaching. Paper presented at the 2004 International Symposium of English for Medical Purposes, Xi' an, China, 2004.
[18] A.S. Al-Thamimi and M. Shuib. Investigating the English Language Needs of Petroleum Engineering Students at Hadhramout University of Science and Technology. The Asian ESP Journal. 2010, 6 (1): 6-34.

[19] T.D. Jick. Mixing Qualitative and Quantitative Methods: Triangulation in Action. Administrative Science Quarterly. 1979, 24 (4): 602-611.

[20] J. Juhary. From a Military Academy to a Defence University: The Needed Transformation. European Scientific Journal. 2012, 8 (8): 1-13.

[21] D.G. Oblinger and J.L. Oblinger. Is it Age or IT: First Steps towards Understanding the Net Generation. In Oblinger, D. G. \& Oblinger, J. L. (eds.). Educating the Net Generation. Educause, 2005.

[22] M. Prensky. Teaching Digital Natives. Corwin, 2010.

\section{Acknowledgements}

The researcher would like to thank all those who have participated in this research. 